\title{
Spinal cord compression in cattle after the use of an oily vaccine ${ }^{1}$
}

\author{
Daniel Guimarães Ubiali², Raquel Aparecida Sales da Cruz², Marconni Victor da Costa \\ Lana $^{2}$,Yara Silva Meireles ${ }^{3}$, Pedro Brandini Néspoli ${ }^{3}$, Marcos Almeida Souza ${ }^{2}$, \\ Edson Moleta Colodel ${ }^{2}$ and Caroline Argenta Pescador ${ }^{2 *}$
}

\begin{abstract}
Ubiali D.G., Cruz R.A.S., Lana M.V.C., Meireles Y.S., Néspoli P.B., Souza M.A., Colodel E.M. \& Pescador C.A. 2011. Spinal cord compression in cattle after the use an oily vaccine. Pesquisa Veterinária Brasileira 31(11):997-999. Laboratório de Patologia Veterinária, Faculdade de Agronomia e Medicina Veterinária, Universidade Federal de Mato Grosso, Av. Fernando Corrêa da Costa 2367, Boa Esperança, Cuiabá, MT 78069-900, Brazil. E-mail: capescador@ufmt.br

An outbreak of compressive myelopathy in cattle associated with the improper use of an oil vaccine is described. Neurological signs were observed in 25 out of 3,000 cattle after 60 days of being vaccinated against foot and mouth disease. The clinical picture was characterized by progressive paralysis of the hind limbs, difficulty in standing up, and sternal recumbency during the course of 2-5 months. A filling defect between the L1 and L3 vertebrae was seen through myelography performed in one of the affected animals. A yellow-gray, granular and irregular mass was observed in four necropsied animals involving the spinal nerve roots and epidural space of the lumbar (L1-L4) spinal cord; the mass was associated with a whitish oily fluid. This fluid was also found in association with necrosis of the longissimus dorsi muscle. Microscopic changes in the epidural space, nerve roots, and spinal musculature were similar and consisted of granulomas or pyogranulomas around circular unstained spaces (vacuoles). These spaces were located between areas of severe diffuse hyaline necrosis of muscle fibers and resembled the drops of oil present in the vaccine.
\end{abstract}

INDEX TERMS: Granuloma, vaccine, neurological disorder, cattle.

\begin{abstract}
RESUMO.- [Compressão medular em bovinos após o uso de vacina oleosa.] Relatamos um surto de mielopatia compressiva lombar em bovinos associada à aplicação de vacina oleosa de forma inadequada. De um total de 3000 bovinos, 25 apresentaram distúrbios neurológicos aproximadamente 60 dias após terem sido vacinados contra a febre aftosa. 0 quadro clínico foi caracterizado por paralisia progressiva de membros posteriores, dificuldade para permanecer em estação e decúbito esternal com evolução de 2-5 meses. A mielografia realizada em um animal revelou defeito de enchimento na altura das vértebras L1 e L3. Quatro animais foram necropsiados e foi visualizado massa
\end{abstract}

\footnotetext{
1 Received on August 2, 2011.

Accepted for publication on August 29, 2011.

${ }^{2}$ Departamento de Clínica Médica Veterinária, Faculdade de Agronomia e Medicina Veterinária, Universidade Federal de Mato Grosso (UFMT), Av. Fernando Corrêa da Costa 2367, Boa Esperança, Cuiabá, MT 78069-900, Brazil. *Corresponding author: capescador@ufmt.br

${ }^{3}$ Laboratório de Diagnóstico por Imagem, Hospital Veterinário (Hovet), Faculdade de Agronomia e Medicina Veterinária, UFMT, Boa Esperança, Cuiabá, MT.
}

tecidual, granular e irregular, envolvendo as raízes nervosas medulares e espaço epidural da região lombar (L1-L4); esse material era associado com líquido brancacento e oleoso. Havia também áreas de necrose no músculo Longissimus dorsi com material similar ao do espaço epidural. Microscopicamente, as alterações observadas no espaço epidural, raízes nervosas medulares e na musculatura foram similares sendo caracterizadas pela formação de múltiplos granulomas ou piogranulomas envolvendo espaços (vacúolos) circulares não corados (aparentemente, o local antes ocupado por gotículas de óleo presente na vacina), além de necrose hialina severa difusa de fibras musculares.

TERMOS DE INDEXAÇÃO: Granuloma, vacina, distúrbio neurológico, bovinos.

\section{INTRODUCTION}

Lesions occupying spaces in the spinal canal are the cause of a syndrome characterized by neurologic dysfunctions such as progressive weakness and paralysis (Callan\& Van Metre 2004, Scott 2004). The most common causes of spinal cord compression in cattle are abscesses in the verte- 
bral body or epidural region, neoplasms, and degenerative or congenital abnormalities in the vertebrae (Radostits et al. 2002). Regardless of the cause, spinal compressions are generally isolated cases, although outbreaks may occur after the use of contaminated injections (Lavely et al. 2006).

Adverse reactions following vaccination include anaphylaxis, iatrogenic infections, injection-site granulomas, endotoxin-induced tissue damage, acute inflammatory demyelinating polyradiculoneuropathy, and neoplasia. The compressive lumbar myelopathy in animals is a recognized iatrogenic complication from injecting water-in-oil vaccines into paravertebral sites (Kleinman et al. 1993, 0'Toole et al. 1995). This paper describes the clinical and pathological features of spinal cord compression in cattle produced by vaccine-associated granulomas.

\section{MATERIALS AND METHODS}

The epidemiological and clinical data were obtained from cattle owner during on site visits to the farm were the outbreak occurred. Postmortem examination was performed on four Nelore cattle and tissue fragments from the spinal cord, brain, liver, kidney, spleen, heart, lungs, intestines, fore stomachs, and abomasum were collected and fixed in $10 \%$ buffered formalin. All samples were stained with hematoxylin and eosin and routinely processed for histology (Allen 1992). Additionally, the samples from the spinal cord were stained using the Steiner's silver and Ziehl-Neelsen acid-fast techniques, and cultured in 5\% sheep blood agar and McConkey's agar plates, aerobically inoculated, and incubated at $37^{\circ} \mathrm{C}$ for 24 to 48 hours. Lumbosacral myelography was performed in one of the affected cattle.

\section{RESULTS}

The disease occurred in January-February 2010, in cattle maintained on a farm located in the Novo Progresso municipality of Pará state, Brazil. Twenty five out of 3,000 cattle were affected by a neurological disorder 60 days after being vaccinated against the foot and mouth disease (FMD). The affected cattle were at different ages, had a fair nutritional condition, and presented a $5 \mathrm{~cm}$ diameter nodular protuberance, commonly on the left side of the lumbar region, involving muscle and subcutaneous tissue.

The clinical signs were consistent with the presence of lumbar spinal cord compression syndrome with progressive paralysis of the hind limbs, characterized by ataxia with signs of dragging the hooves (Fig.1A), crossing of legs when walking, "dog sitting" position with spread limbs, urinary incontinence, and stumbling and falling. This signs lasted for 2-5 months and evolved to sternal recumbency with di-
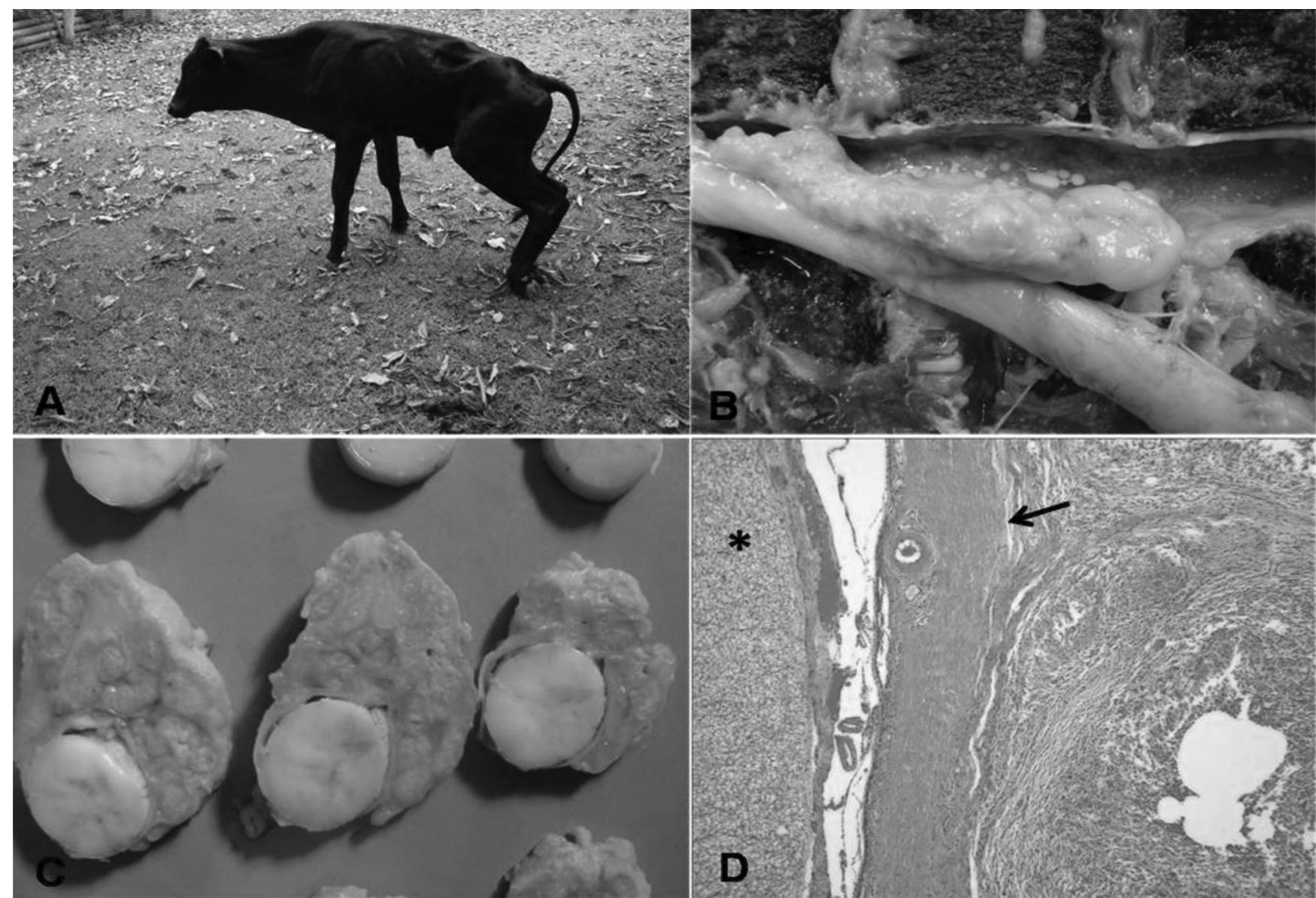

Fig.1. Bovine. Spinal cord compression. (A) Paresis of hind limbs and dragging hooves. (B) A granulomatous mass appears in the epidural space of spinal canal. (C) Transversal sections of spinal cord enclosed by a large epidural granulomatous mass. (D) Dura mater (arrow). Spinal cord (asterisk). Marked granulomatous meningitis surrounding unstained lipidic-like round spaces in the epidural space. HE, obj.20x. 
fficulty to rise. The sensory and motor reflexes of the forelimbs were normal.

The lumbosacral myelography revealed contrast retention at the L4 vertebra and an intradural lesion, which extended from the L1 to the L3. Macroscopically, areas of necrosis in the longissimus dorsi muscle, with the presence of grayish yellow material and a lumpy aspect were observed infiltrated between the muscle fibers. In these areas, whitish oily contents, resembling the FMD vaccine, were infiltrated between the intervertebral spaces, in length, from L1 to $\mathrm{L} 4$, in the epidural space and adhered to the periosteum of the vertebral body as well as the dura mater (Fig.1B,C).

Microscopically, granulomatous inflammation surrounding unstained circular spaces (Fig.1D) were observed in the sections from the L1 to L4 lumbar spinal cord in the epidural region, corresponding to the sites where the oil droplets were present. These droplets were also associated with neuronal chromatolysis, mainly in the ventral horns of the gray matter of the spinal cord, and mild to severe Wallerian degeneration in the funiculi, axonal swelling, and gliosis. Severe diffuse hyaline necrosis of muscle fibers associated with granulomatous inflammation, morphologically similar to that described in the spinal canal, was observed in the longissimus dorsi muscle. No bacteria was detected in spinal cord lesions that were examined using special stains. No significant bacterial growth was identified in the cultured spinal cord samples.

\section{DISCUSSION}

The findings described here characterize cases of spinal cord compression caused by granulomas associated with the incorrect inoculation of the FMD vaccine. Vaccines against FMD contain an oil adjuvant (Bier 1990). Adjuvants act non-specifically by increasing the immune response against antigens and are a key component of vaccines. They can cause adverse effects such as anaphylaxis, infection, granulomas at the injection site, and tumors ( $\mathrm{O}^{\prime}$ Toole et al. 1995).

The cases of spinal cord compression described here were attributed to improper vaccination. There is limited information about economic losses due to vaccine reactions in Brazil. The practice of mass vaccination, mainly in beef cattle, has led to the appearance of abscesses in the injection site because of improper exchange of needles and antisepsis procedures during the vaccination process.

The most remarkable histopathological findings in the current study were somewhat similar to those observed in others studies (Hendrick et al. 1991, Kleinman et al. 1993, 0'Toole et al. 2005). The demonstration of osmiophilic lipid-like material surrounding or within the center of pyogranulomas, coupled with the absence of bacterial infection, indicated that the reaction was most likely directed toward a component in the vaccine, in association with the practice of improper procedures.

In domestic animals, which exhibit posterior ataxia and paralysis, a number of differential diagnoses such as fractures, neoplasms (mainly lymphosarcoma), rabies, and botulism should be considered (Sherman et al. 1986). However, most of them have clinical, macroscopic and microscopic different aspects, which were ruled out. In this study, the history of incorrect vaccination procedures was essential to the diagnosis.

The neck is the usual inoculation site for the FMD vaccine. Adequate procedures should always be followed when vaccinating cattle to avoid disorders affecting the animal's health and the cattle business. Paravertebral intramuscular injection sites should be avoided for vaccination purposes when potentially irritating biological products are used.

Acknowledgements.- To Dr. Valéria Dutra, Department of Veterinary Clinics and Microbiology, Federal University of Mato Grosso, for technical assistance. This study was supported by Coordenação de Aperfeiçoamento de Pessoal de Nível Superior (CAPES).

\section{REFERENCES}

Allen T.C. 1992. Hematoxylin and eosin, p.53-58. In: Prophet E.B., Mills B., Arrington J.B. \& Sobin L.H. (Eds), Laboratory Methods in Histotechnology. American Registry of Pathology, Washington, DC.

Bier O. 1990. Microbiologia e Imunologia. 30ª ed. Editora Melhoramentos, São Paulo. 1234p.

Callan R.J. \& Van Metre D.C. 2004. Viral diseases of the ruminant nervous system. Vet. Clin. North Am., Food Anim. Pract. 20:327-362.

Hendrick M.J. \& Dunagan C.A. 1991. Focal necrotizing granulomatous panniculitis associated with subcutaneous injection of rabies vaccine in cats and dogs: 10 cases (1988-1989). J. Am. Vet. Med. Assoc.198:304-305.

Kleinman N.R., Kier A.B., Diaconu E. \& Lass J.H. 1993. Posterior paresis induced by Freud's adjuvant in guinea pigs. Lab. Anim. Sci. 43:364366.

Lavely J.A., Vernau K.M., Vernau W., Herrgsell E.J. \& Lecouteur R.A. 2006. Spinal epidural empyema in seven dogs. Vet. Surgery 35:176-185.

O’Toole D., McAllister M.M. \& Griggs K. 1995. Iatrogenic compressive lumbar myelopathy and radiculopathy in adult cattle following injection of an adjuvanted bacterin into loin muscle: Histopathology and ultrastructure. J. Vet. Diag. Invest. 7:237-244.

O’Toole D., Steadman L., Raisbeck M. \& Torpy R. 2005. Myositis, lameness, and recumbency after use of water-in-oil adjuvanted vaccines in near-term beef cattle. J. Vet. Diagn. Invest. 17:23-31.

Radostits O.M., Gay C.C., Blood D.C. \& Hinchcliff K.W. 2000. Veterinary Medicine. $9^{\text {th }}$ ed. W.B. Saunders, London. 1877p.

Scott P.R. 2004. Diagnostic techniques and clinicopathologic findings in ruminant neurologic disease. Vet. Clin. North Am., Food Anim. Pract. $20: 215-230$

Sherman D.M. \& Ames T.B. 1986. Vertebral body abscesses in cattle: A review of five cases. J. Am. Vet. Med. Assoc. 188(6):608-611. 